\title{
The response of meiofauna to human trampling on coral reefs
}

\author{
VISNU C. SARMENTO, ALINY F.S. BARRETO and PAULO J.P. SANTOS \\ Universidade Federal de Pernambuco, Centro de Ciências Biológicas, Departamento de Zoologia, \\ Av. Prof. Morais Rêgo s/n, 50670-420, Recife, Pernambuco, Brazil. E-mail: visnu.ubi@gmail.com
}

\begin{abstract}
SUMMARY: Coastal environments are trampled by humans worldwide; however, there are few studies that evaluate the effect of trampling on the meiofauna of hard substrates, and none on meiofauna of reef environments. We investigated the effects of trampling due to tourism on the meiofauna of reef formations on the northeastern coast of Brazil. Samples were taken from five paired stations located in two areas on the reef: an area protected since 2004, and an area open to tourist visits. Trampling caused important changes in the meiofaunal assemblage. The densities of the total meiofauna and of the commonest groups were negatively affected in the trampled area. Among the major groups, Polychaeta proved to be very sensitive to this disturbance. The meiofauna groups showed different response patterns to trampling depending on the species of algae trampled. Reductions in animal densities were partly attributed to the loss of turf biomass and associated sand caused by trampling, and partly to the direct effect of people stepping on the animals. Considering the importance of meiofauna in the food web as well as its biodiversity, these results highlight the possible negative effects of human trampling on the ecological and economic "services" that coral reefs provide.
\end{abstract}

Keywords: man-induced effects, ecosystem disturbance, tourism, algae, habitat, benthos, coral reefs.

RESUMEN: RESPUESTA DE LA MEIOFAUNA AL PISOTEO HUMANO EN LOS ARRECIFES DE CORAL. - Los ambientes costeros están sometidos a la frecuentación humana en todo el mundo. Sin embargo, los estudios que evalúan el efecto de la frecuentación sobre la meiofauna de sustratos duros son raros, y sobre la meiofauna de los ambientes arrecifales son inexistentes. Se investigaron los efectos de la frecuentación relacionados con el turismo en la meiofauna de formaciones de arrecifes costeros en la región nordeste de Brasil. Fueron recogidas muestras de cinco pares de estaciones ubicadas en dos zonas en el arrecife: un área protegida desde 2004, y un área abierta a las visitas de turistas. La frecuentación provocó cambios importantes en la comunidad de la meiofauna. Las densidades de la meiofauna total y de los grupos más frecuentes fueron afectadas negativamente en la zona pisoteada. Entre los grupos principales, la clase Polychaeta demostró ser muy sensible a esta perturbación. Los grupos de la meiofauna mostraron diferentes padrones de respuesta al pisoteo dependiendo de la especie de alga pisoteada. Las reducciones en la densidad de animales se debieron en parte a la pérdida de biomasa de algas y sedimento asociado causada por el pisoteo, y en parte al efecto directo del pisoteo sobre los animales. Considerando la importancia de la meiofauna en la cadena alimentaria y su biodiversidad, estos resultados llaman la atención sobre los posibles efectos negativos de la frecuentación humana en los "servicios" ecológicos y económicos que proporcionan los arrecifes.

Palabras clave: acción antropogénica, perturbación del ecosistema, turismo, algas, hábitat, bentos, arrecifes de coral.

\section{INTRODUCTION}

Trampling is a human disturbance originating in outdoor recreational activities, and its destructive effects have been documented in terrestrial and marine environments (Liddle, 1997). This impact is common in coastal ecosystems, as people walk on sandy and rocky intertidal zones in many parts of the world
(Brown and Taylor, 1999; Davenport and Davenport, 2006; Defeo et al., 2009).

Coral reefs are among the most prominent marine ecosystems of tropical Brazil. These reefs are distributed along $3000 \mathrm{~km}$ of the northeastern coast, and they include the southernmost coral reef communities of the Atlantic. The Brazilian coral reefs form structures that are significantly different from most of the well-known 
coral reef models in the world (Leão and Dominguez, 2000). In addition to the ecological importance of these unique reef ecosystems, they provide direct and indirect economic benefits related to fisheries and ecotourism (White et al., 2000).

Uncontrolled urban development and unplanned tourism activities are responsible for different kinds of human impacts on the Brazilian coastal zone (Maida and Ferreira, 1997; Leão and Dominguez, 2000; Costa Jr. et al., 2008; Ferreira and Rosso, 2009). In the northeast region of Brazil, the reef formations located at Porto de Galinhas beach in the state of Pernambuco are one of the most important tourist destinations in the country. However, they are vulnerable ecosystems because they are easy to access, which allows thousands of people to disembark and walk freely across them at low tide (Alcantara et al., 2004).

The surface of these reefs is usually covered by zoanthids and thick algal mats (Maida and Ferreira, 1997), and the meiofauna is one of the assemblages affected by trampling in the reef phytal environment. Defined as a biologically and ecologically separate group of metazoans that are trapped between meshes of $0.044 \mathrm{~mm}$ (or $0.062 \mathrm{~mm}$ ) and $0.5 \mathrm{~mm}$ (or $1 \mathrm{~mm}$ ) (Giere, 2009), meiofauna animals are likely to be more abundant than macrofauna by at least an order of magnitude in the turf (Gibbons and Griffiths, 1986). Meiofauna densities of up to $10^{6}$ individuals $/ \mathrm{m}^{2}$ of turf coverage are not uncommon, and some phytal environments are considered "hot spots of meiofaunal production", attaining values around 10 g.C. $\mathrm{m}^{-2} \cdot \mathrm{y}^{-1}$ (Giere, 2009). Meiofauna organisms may occupy different microhabitats in the phytal substrate, including the surface of the fronds, the interstices of holdfasts, and the sediment and detritus that accumulate at the bases of the stems (Hicks, 1977; Arroyo et al., 2004). The metazoan meiofauna is a key component of the coastal benthos, contributing significantly to the energy transfer to higher trophic levels (Coull, 1988; Danovaro et al., 2007). Although meiofaunal organisms are usually scarce on bare reefs, valuable meiofauna food is available in algal mats and represents an additional food source, mainly for macrofauna, shrimp and small fish (Giere, 2009).

Meiofauna has been used to investigate the effects of human impacts and particularly the impact of trampling on different environments. Gheskiere et al. (2005) demonstrated that trampling related to tourism was affecting the sandy beach meiofauna in the upper beach zone on the Hel Peninsula (Poland) and in San Rossore (Tuscan region). Wynberg and Branch (1997) assessed the responses of the meiofauna associated with bait-collection of the sandprawn Callianassa kraussi in a marine lagoon on the west coast of South Africa. In mangrove sediments of the Towra Point Aquatic Reserve in Botany Bay (south of Sydney, Australia), Dye (2006) evaluated the effects of the physical disturbance caused by trampling on meiobenthos. Johnson et al. (2007) investigated the effects on meio- fauna communities in mudflats disturbed by trampling associated with crab-tiling and their recovery in the Yealm Estuary (Devon, England). However, there are few studies that evaluate the effect of human trampling on the meiofauna of hard substrates, and none on reef environments.

Although a reasonable body of literature documents the effects of trampling, few papers are concerned with the effect of human trampling on the abundance of small phytal-dwelling invertebrates (including meiofaunal sized organisms) on rocky shores (Casu et al., 2006a; b). In a study on Asinara Island in the northwestern Mediterranean, Casu et al. (2006a) carried out two experiments to infer the effects of human trampling on small phytal-dwelling invertebrates $(>100 \mu \mathrm{m})$. In the descriptive study (an observational experiment) the authors compared a visited area (Sabina Bay) with two control areas (Sant'Andrea Bay and Arena Bay), and only found significant differences in the abundance of isopods and caprellid amphipods but stated that differences in these taxa were not likely to be due to tourism. On the other hand, with the manipulative experimental approach applied inside the two protected areas (Sant'Andrea Bay and Arena Bay) Casu et al. (2006a) showed that two experimental trampling intensities, based on the trampling intensities registered in Sabina Bay, can cause decreases in the abundances of many taxa.

The present study evaluated the effect of human trampling due to tourism on the phytal meiofauna assemblage in two areas on the reefs of Porto de Galinhas: an area that has been protected since 2004, and an area that is continuously open to visitors. Two hypotheses were tested: trampling significantly reduces the density of major taxonomic groups of meiofauna, the turf height, biomass, sand content, and algal cover; and trampling significantly alters the meiofauna assemblage structure.

\section{MATERIALS AND METHODS}

\section{Study area}

Data were collected on February 25, 2009 on the reefs of Porto de Galinhas Beach. These formations have a total area of $0.42 \mathrm{~km}^{2}$, and are located between the coordinates $8^{\circ} 30^{\prime} 26^{\prime \prime}$ to $8^{\circ} 30^{\prime} 41^{\prime \prime} \mathrm{S}$ and $34^{\circ} 59^{\prime} 52^{\prime \prime}$ to $34^{\circ} 59^{\prime} 55^{\prime \prime} \mathrm{W}$ (Fig. 1). From November to March and in July, Porto de Galinhas receives up to 65000 visitors monthly. The assessment of the effects of trampling on phytal meiofauna was conducted on the reef visited by most tourism rafts (Fig. 1). In this area, large numbers of tourists (1020 people over one low-tide period) are taken daily by rafts for tours that last about $45 \mathrm{~min}$. On this same reef, there are areas that have been permanently conserved since 2004 (between 2004 and 2009, $70 \%$ of the total reef area was protected). These areas are marked by buoys and ropes, and tourists are not allowed to enter. 


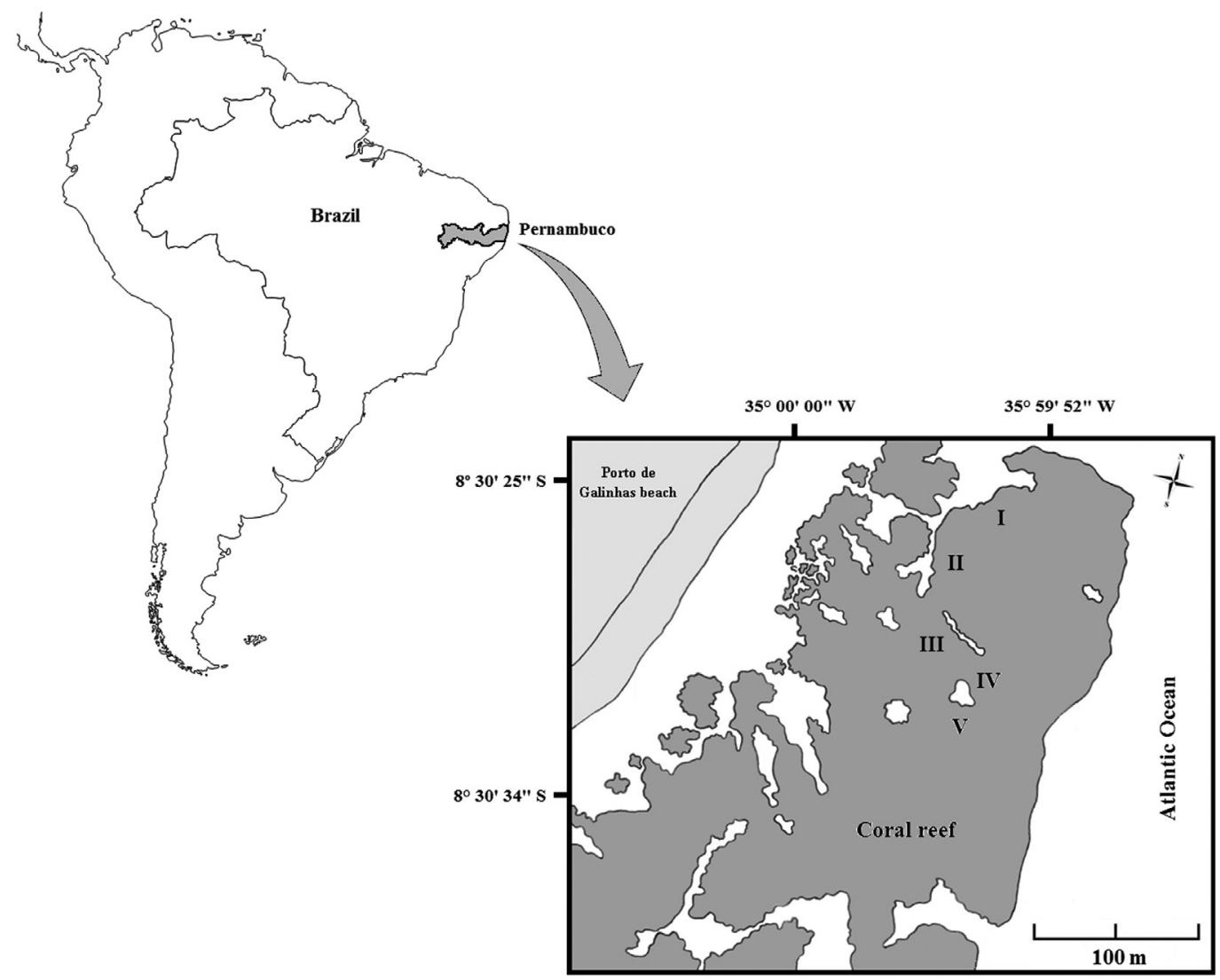

FIG. 1. - Study area showing the location of the five sampling stations (I to V) along the reef visited by most tourism rafts at Porto de Galinhas (northeastern Brazil).

\section{Data collection}

To investigate the impacts of trampling from human visitors, we selected five (I to V) paired groups of stations located along the reef surface. Each pair had a station outside (I to V - Trampled) and inside (I to V - Protected) the protected area. The paired design was used to minimize the station-to-station variability due to factors other than human use, such as temperature, exposure to wave activity, reef topography or heterogeneity in the turf species distribution. Three replicate samples were collected per station.

Samples were taken using a corer with an area of $10 \mathrm{~cm}^{2}$. The turfs were collected by cutting the turf down to the reef surface using a metal scraper to ensure that all turf and underlying sediment were removed. Meiofauna samples were preserved in $4 \%$ formalin in seawater in the field and taken to the laboratory. During sampling, the turf height was obtained for each replicate by measuring it close to the sample core area using a caliper (precision $0.1 \mathrm{~mm}$ ) inserted into the reef surface. Photographs of the sampling stations were taken to obtain the percentage of algal cover in the two study areas. Photo-quadrats of $0.27 \mathrm{~m}^{2}(0.45 \times 0.60 \mathrm{~m})$ were analyzed by examination of points in a grid with 100 intersections; the percent cover was equal to the number of points lying over the algae.
Digital videos were taken during low tide in four different locations of the area open to visitors. The analysis of 5 min videos of $4 \mathrm{~m}^{2}$ areas at each location was used to assess the average trampling rate (estimated as the number of steps per square meter for a period of $2 \mathrm{~h}$ ) during the peak tourist season in 2009.

In the laboratory, the fauna was extracted by manual elutriation with filtered water through geological sieves with mesh sizes of $0.5 \mathrm{~mm}$ and $0.063 \mathrm{~mm}$. The meiofauna retained between the sieves was analyzed under a Leica EZ4 stereomicroscope to evaluate the densities of the major meiofaunal groups. The algae species were identified for each replicate. After fauna extraction, the algal biomass and the sand content were assessed for each replicate. Sand and algal turf were dried separately to constant weight at $60^{\circ} \mathrm{C}$ and weighed to the nearest $0.1 \mathrm{mg}$. Before drying, the proportions of the main algae species were evaluated visually, using the following classes: $\sim 5 \%, \sim 10 \%, \sim 25 \%$, $\sim 50 \%, \sim 75 \%, \sim 90 \%, \sim 95 \%, \sim 100 \%$.

\section{Statistical analysis}

The Bray-Curtis index was applied to untransformed data to assess the similarity among meiofauna samples. Multi-Dimensional Scaling (MDS) was used to represent the similarity matrix graphically in a two-axis 


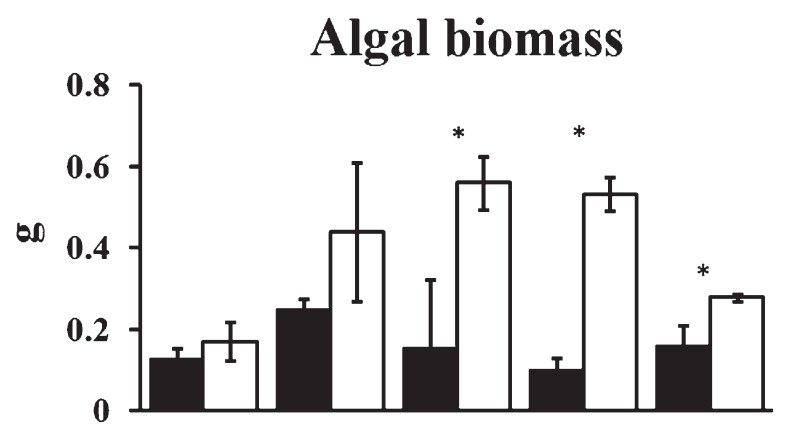

Turf height

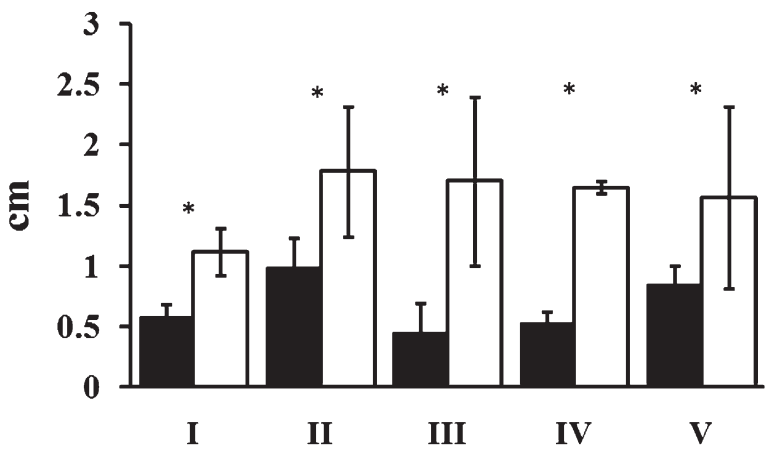

Sediment content

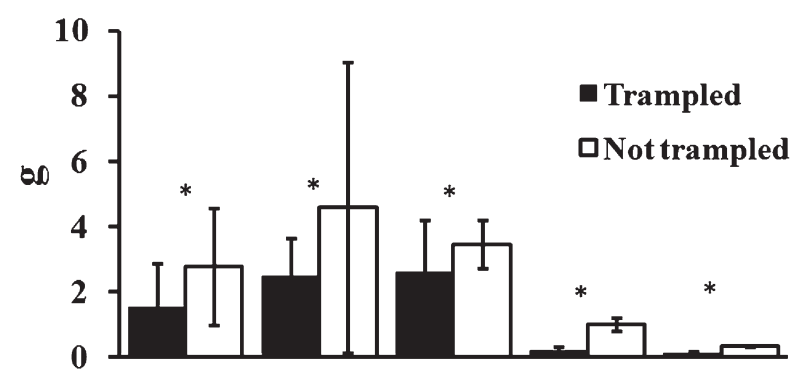

Algal coverage

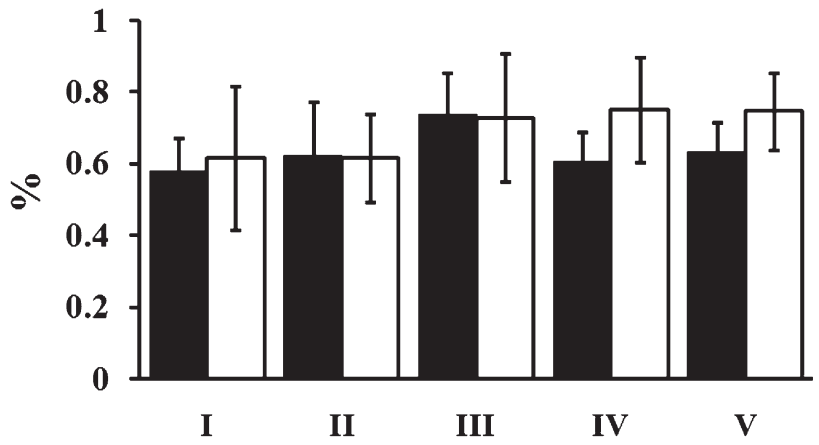

FIG. 2. - Physical characteristics of the phytal substrate (sediment content, turf weight and height, and algal cover) in the protected and trampled areas of five sampling stations (I to V) at Porto de Galinhas in northeastern Brazil. Bars represent means of three replicates $\pm 95 \%$ confidence intervals. * Indicates significant differences between trampled and protected areas.

TABLE 1. - Analysis of variance (two-way ANOVA) results for the physical characteristics of the phytal substrate at Porto de Galinhas reef in northeastern Brazil. ( $\mathrm{df}=$ degrees of freedom; MS: mean square). Significant F values in bold.

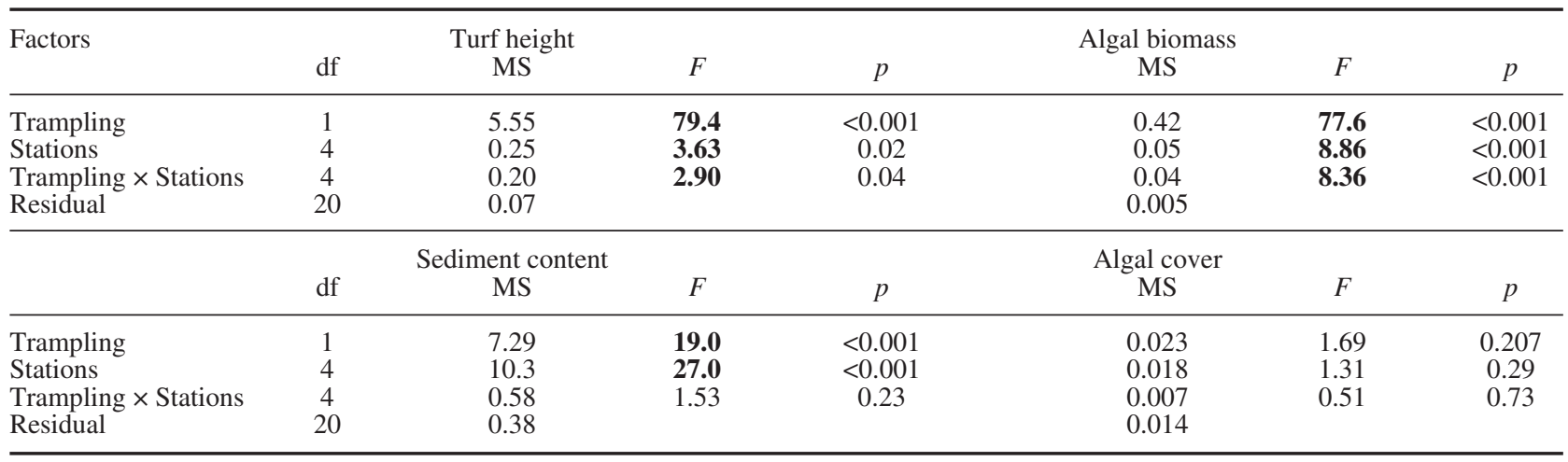

space. Analysis of similarity (two-way ANOSIM) was used to assess significant differences in the structure of the meiofaunal assemblage between protected and trampled areas and among the five sampling stations.

Two-way analysis of variance (ANOVA) was employed to examine the effects of trampling on the physical characteristics of the phytal substrate, algal biomass, sediment content, turf height and algal cover, between the two areas and among the five sampling stations. This same analysis was used to examine the trampling effect on the densities of total animals and on the densities of the main meiofaunal groups. Two fixed factors were utilized for the ANOVA: trampling and stations. The heterogeneity of variances was verified with the Bartlett test, and the abundance of Acari,
Harpacticoida, Nauplii, Nematoda, Oligochaeta, Polychaeta and Tardigrada as well as sediment content and turf height were transformed to a natural logarithm of $(\mathrm{x}+1)$ prior to analysis. Other variables were analyzed untransformed. The Fisher LSD test was used for $a$ posteriori comparison when the interaction between factors was significant.

To detect if differences in total meiofauna density between protected and trampled areas could be related only to the amount of substrate available, a covariance analysis (ANCOVA) was performed. In this analysis, trampling was considered as the single factor, total meiofauna density (in $10 \mathrm{~cm}^{2}$ ) as the dependent variable, and total substrate weight as the co-variable. The substrate weight was obtained from the sum of dry 
TABLE 2. - Analysis of variance (two-way ANOVA) results for the main meiofaunal groups at Porto de Galinhas reef in northeastern Brazil. (df, degrees of freedom; MS, mean square) Significant F values in bold.

\begin{tabular}{|c|c|c|c|c|c|c|c|}
\hline \multirow[t]{2}{*}{ Factors } & \multicolumn{3}{|c|}{ Nematoda } & \multicolumn{4}{|c|}{ Harpacticoida } \\
\hline & df & MS & $F$ & $P$ & MS & $F$ & $p$ \\
\hline Trampling & 1 & 19.81 & 75.8 & $<0.001$ & 8.24 & 48.54 & $<0.001$ \\
\hline Stations & 4 & 1.26 & 4.83 & $<0.01$ & 2.21 & 13.04 & $<0.001$ \\
\hline Trampling $\times$ Stations & 4 & 3.24 & 12.4 & $<0.001$ & 0.54 & 3.16 & 0.036 \\
\hline \multirow[t]{3}{*}{ Residual } & 20 & 0.26 & & & 0.17 & & \\
\hline & & Polychaeta & & & Turbellaria & & \\
\hline & df & MS & $F$ & $p$ & MS & $F$ & $p$ \\
\hline Trampling & 1 & 26.81 & 60.3 & $<0.001$ & 15400 & 42.1 & $<0.001$ \\
\hline Stations & 4 & 1.83 & 4.12 & 0.01 & 133000 & 4.87 & $<0.01$ \\
\hline Trampling $\times$ Stations & 4 & 2.91 & 6.54 & 0.002 & 10100 & 3.21 & 0.03 \\
\hline \multirow[t]{3}{*}{ Residual } & 20 & 0.444 & & & 3162 & & \\
\hline & & Nauplii & & & Tardigrada & & \\
\hline & $\mathrm{df}$ & MS & $F$ & $p$ & MS & $F$ & $p$ \\
\hline Trampling & 1 & 8.88 & 51.96 & $<0.001$ & 0.347 & 0.70 & 0.41 \\
\hline Stations & 4 & 1.85 & 10.80 & $<0.001$ & 4.913 & 9.94 & $<0.001$ \\
\hline Trampling $\times$ Stations & 4 & 2.18 & 12.79 & $<0.001$ & 4.462 & 9.03 & $<0.001$ \\
\hline \multirow[t]{3}{*}{ Residual } & 20 & 0.171 & & & 0.49 & & \\
\hline & & Ostracoda & & & Acari & & \\
\hline & df & MS & $F$ & $p$ & MS & $F$ & $p$ \\
\hline Trampling & 1 & 26000 & 2.60 & 0.12 & 5.28 & 21.1 & $<0.001$ \\
\hline Stations & 4 & 114000 & 11.35 & $<0.01$ & 0.92 & 3.70 & 0.02 \\
\hline Trampling $\times$ Stations & 4 & 208000 & 20.81 & $<0.01$ & 1.14 & 4.55 & $<0.01$ \\
\hline \multirow[t]{3}{*}{ Residual } & 20 & 10010 & & & 0.25 & & \\
\hline & & Total meiofauna & & & Oligochaeta & & \\
\hline & $\mathrm{df}$ & MS & $F$ & $p$ & MS & $F$ & $p$ \\
\hline Trampling & 1 & 7510000 & 68.77 & $<0.001$ & 5.30 & 6.38 & 0.02 \\
\hline Stations & 4 & 1330000 & 12.14 & $<0.001$ & 0.84 & 1.01 & 0.42 \\
\hline Trampling $\times$ Stations & 4 & 1330000 & 12.18 & $<0.001$ & 0.97 & 1.17 & 0.35 \\
\hline Residual & 20 & 109318 & & & 0.83 & & \\
\hline
\end{tabular}

sediment content and algal biomass wet weight. The heterogeneity of variances of the variables total meiofauna density and substrate weight was verified with the Bartlett test, and the null hypothesis of the parallelism of the regression lines was tested. The significance of the effect of substrate weight on total meiofauna density was also calculated.

MDS and ANOSIM analyses were carried out using the software Primer ${ }^{\circledR}$ v.6 (Plymouth Routines in Multivariate Ecological Researches). The two-way ANOVA and ANCOVA were calculated using the software STATISTICA 7.0.

The level of significance was set at $p<0.05$ for all analyses. Multivariate analysis was based on the methods proposed by Clarke and Warwick (1994), and for the parametric statistical analysis we followed Zar (1996).

\section{RESULTS}

\section{Trampling effects on phytal habitats}

The algal turfs showed a heterogeneous composition and distribution throughout the reef. The turfs covering the reef surface of the study area were mainly formed by two algal species: Chondrophycus papillosus (Agardh) Garbary and Harper and Gelidiella acerosa (Forsskal) Feldmann and Hamel. At station I (trampled and protected areas), the turfs were formed exclusively by $C$. papillosus, while G. acerosa was the main species $(>75 \%)$ forming the turfs sampled at the other four stations (stations II to $\mathrm{V}$ in the trampled and protected areas). Inside the turfs, the mean temperature was $35^{\circ} \mathrm{C}$, and ranged from 32.5 to $37^{\circ} \mathrm{C}$.

The analysis of the remote videos revealed that Porto de Galinhas reefs open to tourist visits had a mean trampling rate of 620 footsteps $\mathrm{m}^{-2} 2 \mathrm{~h}^{-1}$ (standard deviation $=228$ footsteps $\mathrm{m}^{-2} 2 \mathrm{~h}^{-1}$ ), with maximum and minimum values of 855 and 337 footsteps $m^{-2} 2 \mathrm{~h}^{-1}$ respectively.

The effect of human trampling on the physical characteristics of the phytal substrate is illustrated in Figure 2. The percentage of algal cover on the reef surface did not show any significant differences between trampled and protected areas or stations, or for the interaction between factors (Table 1). However, turf height was significantly different for the factors trampling and stations, and also for the interaction between these factors, although the results for stations and interaction were only weakly significant $(0.01<\mathrm{p}<0.05)$. Algal biomass was highly 
Total meiofauna

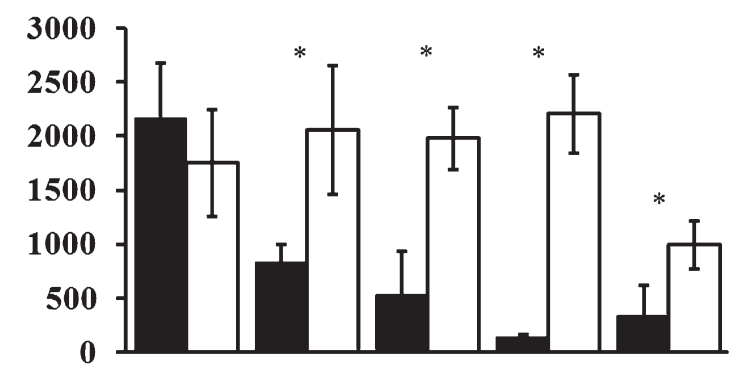

Acari
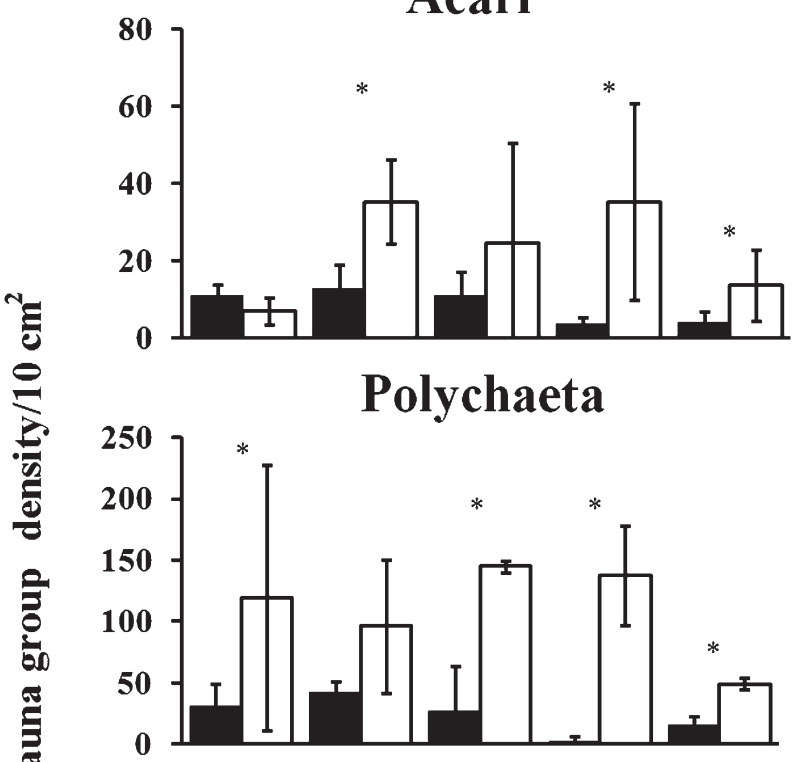

Nauplius

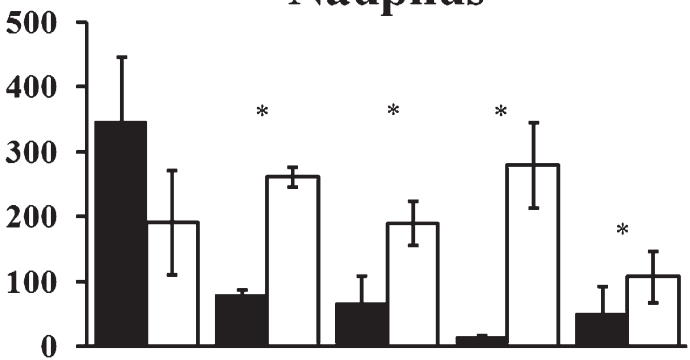

Nematoda

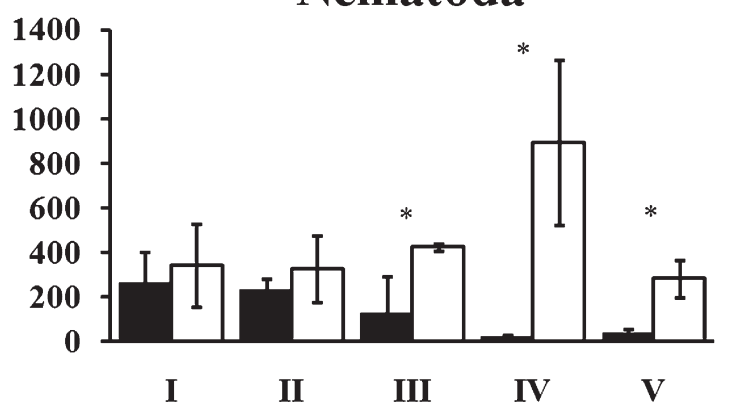

Tardigrada

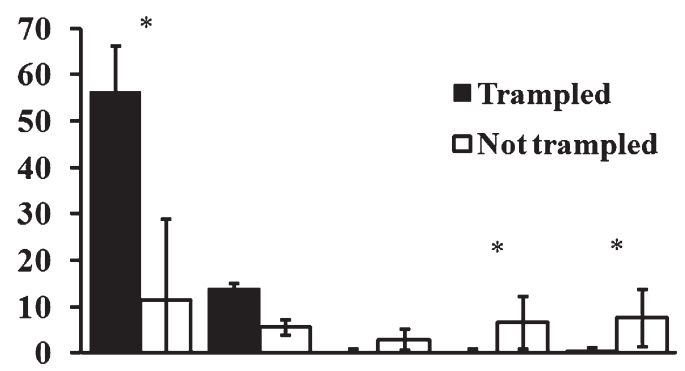

Harpacticoida

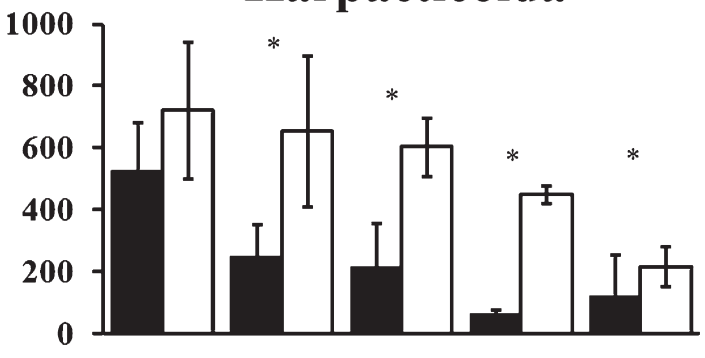

Turbellaria

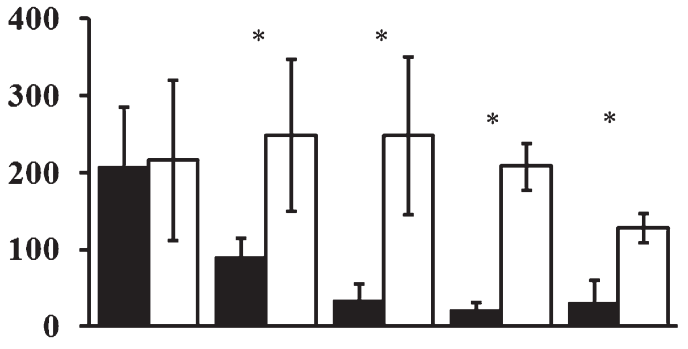

\section{Ostracoda}

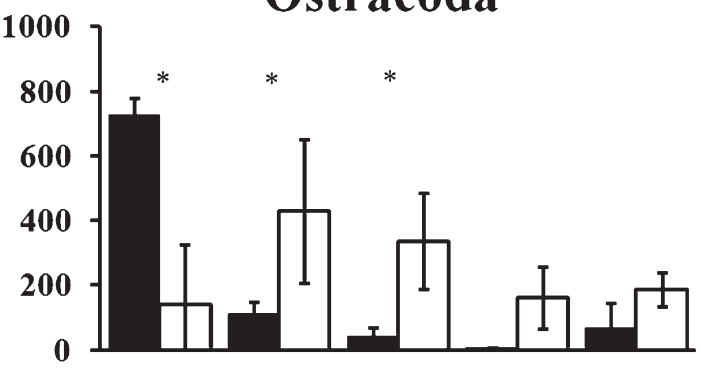

\section{Oligochaeta}

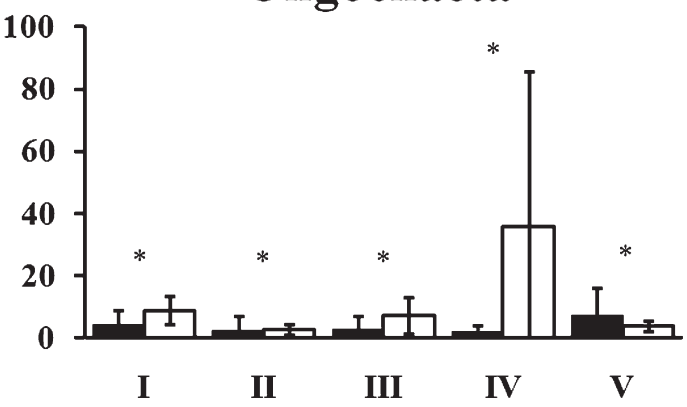

FIG. 3. - Densities of total meiofauna and of the main groups of meiofauna (individuals $/ 10 \mathrm{~cm}^{2}$ ) for protected (white bars) and trampled (black bars) areas at the five sampling stations (I to V) at Porto de Galinhas in northeastern Brazil. Bars represent the mean of three replicates $\pm 95 \%$ confidence intervals. * Indicates significant differences between trampled and protected areas. 
TABLE 3. - Results of the Fisher LSD test $(p)$ for densities of the main meiofaunal groups and total meiofauna at each sampling station that showed significant interactions $(\mathrm{p}<0.05)$ between the factors trampling and stations (symbols: $=$ non-significant differences; $\uparrow$ significant increase; $\downarrow$ significant decrease).

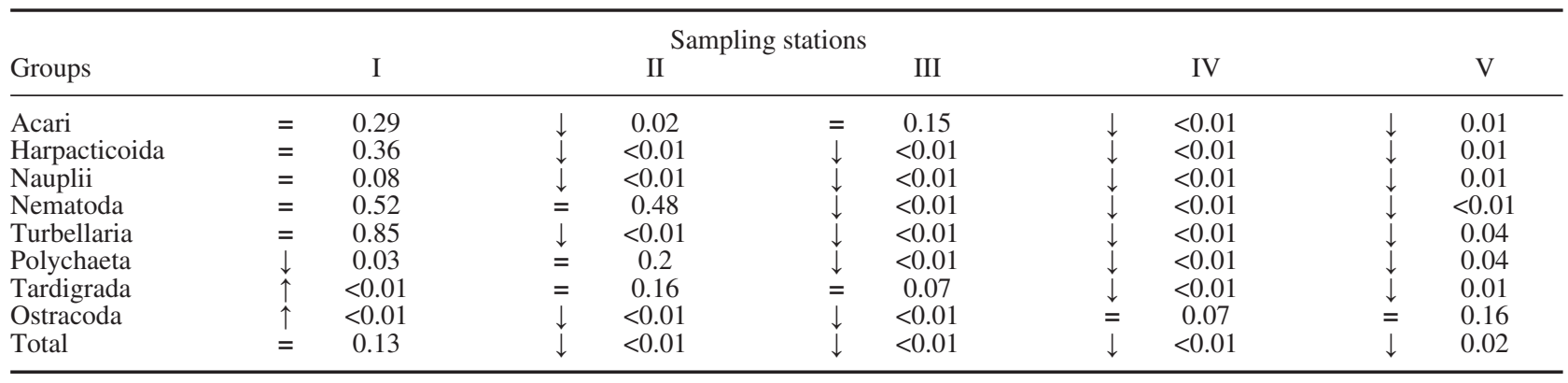

significant for the factors trampling and stations, and also for the interactions between the two factors. Sediment content associated with the turf also showed highly significant results for the factors trampling and stations, but not for the interaction between factors. Although the turf height showed significant interaction between factors, the a posteriori test (Fisher LSD) indicated that the turf height was lower $(\mathrm{p}<0.01)$ in the trampled area compared to the protected area at all five sampling stations. Considering the variable algal biomass, stations I $(p=0.49)$ and II $(p=0.06)$ did not show significant reductions between trampled and protected areas, while in the other stations the algal biomass was significantly reduced in the trampled area $(\mathrm{p}<0.01)$.

\section{Trampling effects on the meiofauna assemblage}

A total of 39485 animals was counted: 27378 animals in the protected area and 12107 in the trampled area. The meiofauna inhabiting the turf algae and sediments covering the reef surface in Porto de Galinhas was composed by the taxa Acari, Bivalvia, Copepoda Harpacticoida, Gastropoda, Gastrotricha, Kinorhyncha, Nematoda, Oligochaeta, Ostracoda, Polychaeta, Polyplacophora, Tardigrada, Turbellaria and Tanaidacea. In the protected area the dominant groups were Copepoda Harpacticoida (40.86\%), Nematoda (25.18\%), Ostracoda (13.9\%), Turbellaria (11.64\%) and Polychaeta $(6.08 \%)$. In the area disturbed by trampling, the main taxa were Copepoda Harpacticoida (43.34\%), Ostracoda $(23.91 \%)$, Nematoda $(16.91 \%)$ and Turbellaria $(9.57 \%)$.

Total densities of meiofauna were rather high, with a mean of $1801.5( \pm 479.4$ standard deviation $)$ individuals $/ 10 \mathrm{~cm}^{2}$ in the protected area (minimum 996.3 individuals $/ 10 \mathrm{~cm}^{2}$ at station $\mathrm{V}$ and maximum 2211.7 individuals $/ 10 \mathrm{~cm}^{2}$ at station IV) and $800.9( \pm 809.5$ standard deviation) individuals $/ 10 \mathrm{~cm}^{2}$ in the trampled area (minimum 134.7 individuals $/ 10 \mathrm{~cm}^{2}$ at station IV and maximum 2173.3 individuals $/ 10 \mathrm{~cm}^{2}$ at station I). The effects of trampling on the densities of total meiofauna, as well as on the most abundant taxa at the five sampling stations, are shown in Figure 3.

The two-way ANOVA results (Table 2) indicated that all groups except Oligochaeta showed significant interactions between the factors trampling (trampled vs. protected area) and stations. Despite the low densities in the study area, Oligochaeta showed a weakly significant difference only for the factor trampling. Ostracoda and Tardigrada showed highly significant results for the interaction between factors. However, the large increase in the density of these two groups in the trampled area of station I prevented detection of significant differences for the factor trampling alone (Table 2).

Table 3 illustrates the results of the a posteriori test (Fisher LSD) for the main meiofaunal groups that showed a significant interaction between the factors trampling and stations. The data in this table show that the effect of trampling led to different response patterns among the meiofaunal groups along the sampling stations on the reef. In spatial terms, we can highlight two groups of sampling stations according to the sharp differences observed in their response patterns to trampling: station I vs. stations II to V. At station I, the total meiofauna $(p=0.13)$ density and the densities of the groups Acari $(\mathrm{p}=0.29)$, Copepoda Harpacticoida $(\mathrm{p}=0.3)$, Nauplii $(\mathrm{p}=0.08)$, Nematoda $(\mathrm{p}=0.52)$ and Turbellaria $(\mathrm{p}=0.85)$ did not show significant differences between the protected and trampled areas. Of the three groups that showed significant differences at this station, Ostracoda $(\mathrm{p}<0.01)$ and Tardigrada $(\mathrm{p}<0.01)$ increased in density and Polychaeta $(\mathrm{p}<0.03)$ decreased in density in the trampled area (Fig. 3). Significant differences for most groups were observed in stations II to $\mathrm{V}$, and these differences were always expressed by density reductions in the trampled area (Table 3 and Fig. 3).

The analysis of covariance (ANCOVA) was performed to test whether the reduction in the density of total meiofauna was merely due to the reduction in weight of the substrate. Only the data from stations II to $\mathrm{V}$, which showed significant substrate reductions, were used in this analysis. The test for parallelism of regression lines indicated that there were no significant differences in the slopes $\left(\mathrm{F}_{(1 ; 26)}=0.925 ; \mathrm{p}=0.348\right)$. In addition to the significant positive effect of substrate weight $\left(\mathrm{F}_{(1 ; 27)}=9.66 ; \mathrm{p}=0.005 ; \mathrm{R}^{2}=0.315\right)$, the $\mathrm{AN}$ COVA also detected even stronger significant differences in meiofauna density due to the trampling effect $\left(\mathrm{F}_{(1 ; 27)}=34.39 ; \mathrm{p}<0.001\right)$. 


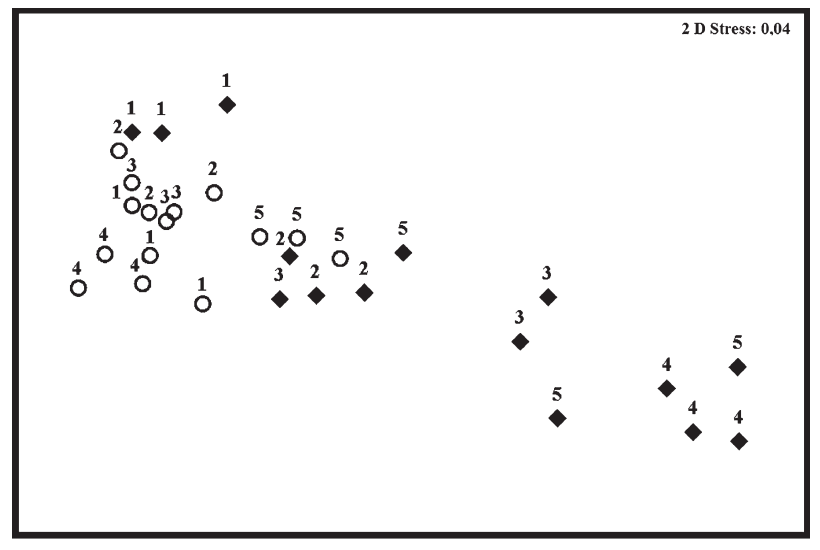

FIG. 4. - MDS ordination of the meiofauna assemblage (major groups) collected at protected (circles) and trampled (diamonds) areas at the five (I-1 to V-5) sampling stations at Porto de Galinhas reef, northeastern Brazil.

The MDS analysis represented very well (stress = $0.04)$ the similarity matrix among meiofauna samples from both the protected and trampled areas at the five stations sampled (Fig. 4). This analysis indicated that there were evident differences in the structure of the meiofaunal assemblage (major groups) between protected and trampled areas, as well as marked differences among the five sampling stations. Moreover, the analysis showed that the trampled replicates of station I were more similar to the full set of replicates of the protected area than to replicates taken in the trampled area.

The pattern illustrated in the MDS ordination was confirmed by ANOSIM. Highly significant differences in the structure of the meiofauna assemblage were detected between the protected and trampled areas $\left(R_{\text {global }}=0.815, p<0.001 \%\right.$, number of permutations $=10000)$ and between sampling stations $\left(\mathrm{R}_{\text {global }}=0.654\right.$, $\mathrm{p}<0.001 \%$, number of permutations $=10000$ ).

\section{DISCUSSION}

Several studies have investigated the effects of human trampling on hard-substrate communities. However, the majority of these studies applied a manipulative experimental approach (Bally and Griffiths, 1989; Povey and Keough, 1991; Brosnan and Crumrine, 1994; Fletcher and Frid, 1996; Keough and Quinn, 1998; Schiel and Taylor, 1999; Jenkins et al., 2002; Milazzo et al., 2002, 2004). Despite the different methodologies applied in these manipulative experiments, the results indicated that human trampling disturbance has a negative effect on the benthic communities of many geographical regions. In New Zealand, Brown and Taylor (1999) found a strong negative effect of trampling on total macrofauna densities, on some macrofauna group densities, and on coralline algal biomass and sand content. On the east coast of the Asinara Island Marine Protected Area (Italy, Mediterranean Sea), Casu et al. (2006b) found a significantly higher abundance of some benthic animals in controls compared to experimentally trampled plots. Ferreira and Rosso (2009) applied experimental trampling to rocky-shore fauna dominated by Chthamalus bisinuatus (Cirripedia) and Isognomon bicolor (Bivalvia) on the coast of São Paulo (southeastern Brazil) and found that this assemblage is sensitive to trampling. Milazzo et al. (2002) studied macroalgal species within the integral reserve of the Ustica Island Marine Protected Area (Italy, Mediterranean Sea) and found that the higher levels of disturbance caused by human trampling significantly affected both algal percentage cover and canopy, as well as its recovery (Milazzo et $a l ., 2004)$. On the rocky shore of Praia Norte in Viana do Castelo (NW Portugal), Araújo et al. (2009) showed that experimental trampling negatively affected the macroalga Ascophyllum nodosum assemblage and also the subsequent temporal evolution of the assemblages. Finally, studying rocky intertidal algal assemblages, Keough and Quinn (1998) in Australia and Schiel and Taylor (1999) in New Zealand also demonstrated the strong negative effect of experimental trampling on Hormosira beds and the associated organisms.

Although the number of studies that have used observational experiments to assess the effect of human trampling associated with tourism in coastal environments is growing, most of this work has not been performed on hard substrates (Andersen, 1995; Fanini et al., 2005; Grunewald, 2006; Veloso et al., 2006; Kerbiriou, 2008; Hsu et al., 2009). Unlike the manipulative experimental studies, the studies that assess the damage caused by human trampling of hard substrates by comparing areas open to visitors with protected (or little-used) areas have yielded conflicting results, which makes it difficult to conclude that trampling has a negative impact on benthic communities. To assess the human trampling effect due to tourism, Casu et al. (2006a) compared the abundance of the fauna retained on mesh size $>100 \mu \mathrm{m}$ (macrofauna plus part of the meiofaunal organisms) associated with rocky-shore algae in two Marine Protected Areas and one area open to tourists, located on the east coast of Asinara Island (northwestern Mediterranean). In this study, Casu et al. (2006a) did not find differences among the abundances of taxa collected during the summer at the visited station (Cala Sabina) and the taxa sampled at the control stations (Cala Arena and Cala Sant'Andrea). Similarly, Batista et al. (2009), who compared the population structure of Microphrys bicornutus (Brachyura, Mithracidae) in the Halimeda opuntia (Halimedaceae) phytal in two reef areas in northeastern Brazil, Picãozinho (visited by tourists) and São Gonçalo (control area), did not find differences in algal biomass or the crustacean population parameters between the reefs. In contrast to these studies, at the Purbeck Marine Wildlife Reserve within the boundary of the Dorset and East Devon World Heritage Site on the south coast of the UK, Pinn and Rodgers (2005) investigated the influence of visitors on the 
intertidal biodiversity of macrobenthos at Kimmeridge Bay. The authors compared two rock ledges: Washing Ledge (a heavily visited site within the confines of the bay) and Yellow Ledge (a less visited site to the east of the bay where relatively few visitors venture), and found differences in algae composition and limpet abundance between the ledges. In addition, Van de Werfhorst and Pearse (2007) ranked three sites as undisturbed, severely and intermediately disturbed based on the numbers of visitors to the rocky intertidal platform adjacent to Natural Bridges State Beach, California. In this study, the authors clearly demonstrated that the density and distribution of people correlated positively with the proportion of bare rock, and negatively with species richness, species diversity, and abundance of mussels and rockweeds. Finally, studying mussel populations (Mytilus californianus) on the California coast, Smith et al. (2008) found that biomass, percent cover, and adult densities of mussels were significantly lower at the human high-use sites compared to the low-use sites.

On the reefs of Porto de Galinhas, the trampling associated with tourism had a severe impact on the meiofauna and on most phytal substrate characteristics. Therefore, both of the hypotheses we initially proposed could be accepted. The analysis of similarity showed highly significant differences in the meiofaunal assemblage between the trampled and protected areas, due to the disturbance caused by human trampling. The variance analysis also demonstrated a clearly negative effect of trampling on the densities of the meiofaunal groups. Moreover, this analysis indicated for all groups, except Oligochaeta, that there was a significant interaction between factors (trampling vs. sampling stations), showing that natural differences in the study area were important in the assemblage responses to trampling.

In previous studies of the trampling effect on meioand macrofauna, not all groups showed large reductions in their densities. In one of the few studies that included meiofauna $(>100 \mu \mathrm{m})$ of hard substrates, Casu et al. (2006b) found significantly higher abundances of Nematoda, Polychaeta, Ostracoda, Oligochaeta, Bivalvia, Acari, Amphipoda (caprellids) and Tanaidacea in controls than in experimentally trampled areas, whereas Copepoda Harpacticoida was not significantly affected by trampling. In the present study, Harpacticoida showed significant differences due to trampling at all stations except station I. At stations II to V, the density of Harpacticoida was reduced by $64 \%$ due to trampling. Brown and Taylor (1999) in a study on a macrofaunal assemblage detected a strong negative effect of trampling on total animal densities, and statistically significant reductions in densities of Gastropoda, Polychaeta and Ostracoda two days after experimental trampling ceased (Bivalvia and Nematoda also tended to be negatively affected by trampling). In contrast, densities of Amphipoda (gammarids), Actiniaria (anemones) and Isopoda were relatively unaffected by trampling.
Among the major groups of invertebrates, Polychaeta have been shown to be very sensitive to human trampling. Brown and Taylor (1999) applied a manipulative trampling experiment to macrofauna inhabiting coralline algal turf in northeastern New Zealand, and found that Polychaeta appeared to be particularly vulnerable to trampling, with a substantial decline in density evident at the lowest trampling level. In this study, three months after trampling ended, Polychaeta was the only group that had not returned to control levels. In another manipulative experimental study, Casu et al. (2006c) demonstrated that the Polychaeta assemblage in the Asinara Island MPA (NW Mediterranean) was highly vulnerable to experimental human trampling, which caused immediate declines in the total number of individuals and in some Polychaeta species, even at the lowest experimental level of trampling. The present study, despite its non-manipulative approach, confirmed the great trampling vulnerability of this group. Polychaeta was the only group that consistently showed large reductions in its mean densities, with a $76 \%$ decrease in density in the trampled areas.

It is reasonable to expect that people stepping directly on the animals would have an important impact, crushing or breaking the organisms and/or damaging their tegument or hard shells. However, there is no clear relationship between the direct effects of human trampling and the vulnerability of the taxa based on their morphology (Brown and Taylor, 1999; Casu et al., 2006b). Although there are several ways in which trampling may reduce densities of turf-dwelling animals, such as the direct effect of the crushing impact of footsteps, Brown and Taylor (1999) suggested that it is more likely that the effects of trampling on animal densities are indirect, through changes caused to the turf itself due to loss of plant tissue, rather than the result of compression. In the study by Brown and Taylor (1999), the magnitude of the declines in these phytal physical variables (values at the highest trampling intensity were $41-53 \%$ of the control values) were comparable to the magnitude of the declines in abundance of the taxa most affected by trampling (37-54\%). Therefore, these authors attributed the decrease in animal density to the reduction in available substrate biomass.

In the present study, the magnitude of the reductions in density of the major meiofauna groups due to trampling (64-80\%) was higher compared to the magnitude of the reduction in the phytal substrate characteristics (56-59.5\%). However, the analysis of covariance (ANCOVA) showed that after accounting for the significant effect of substrate loss, it was still possible to detect highly significant differences in meiofaunal density due to the effect of trampling. Here, the density decline in the meiofauna was only partially related to the reduction in the biomass of available substrate.

Compared to the data available in Brown and Taylor (1999), in which remote-video footage revealed average trampling rates of 90 to 430 footsteps $/ \mathrm{m}^{2} / 2 \mathrm{~h}$ on the rocky shore of northeastern New Zealand, tram- 
pling occurs with greater intensity on the reefs of Porto de Galinhas.

On the Porto de Galinhas coral reefs, all meiofaunal groups were affected by human trampling. However, the responses of the groups to trampling varied according to the sampling station. Since the samples were collected at five stations distributed over the reef, these differences may be related to factors other than human use, such as temperature, exposure to wave activity, reef topography or heterogeneity in the distribution of turf species. Among these, the heterogeneity in the turf species distribution along the reef surface was identified as the main factor affecting variation.

It is known that different species of algae may show different responses to human trampling. In a manipulative experimental study carried out within the "no-go zone' of the Ustica Island MPA, Milazzo et al. (2004) showed that algal turfs were more resistant than erect macroalgae to trampling disturbance. They demonstrated that the responses to trampling are species-specific and that algal susceptibility to damage by trampling is likely to depend on their morphology. In addition to demonstrating the different responses of different algal species to trampling, Schiel and Taylor (1999) also demonstrated the importance of recognizing the natural variations before applying the experimental treatment. In an intertidal algal assemblage in southern New Zealand, they showed that there were immediate and longterm effects of trampling, and that Hormosira was the most vulnerable alga to experimental trampling due to the crushing and dislodgement of its fronds. Despite the strong treatment effect on turf and encrusting coralline algal cover, Schiel and Taylor (1999) showed that there was significant variation between transects and platforms because the "pre-treatment" natural variation remained.

The turfs sampled at station I (trampled and protected areas) were formed exclusively by C. papillosus, while $G$. acerosa was the main species forming the turfs sampled at the other four stations. The ANOVAs and MDS indicated that meiofaunal groups inhabiting $C$. papillosus showed a different response pattern to trampling. At the other stations, where G. acerosa dominated, the response pattern of the meiofauna groups was relatively homogeneous.

The two algal species also showed different responses to trampling. For example, in the trampled area of station I, C. papillosus showed the smallest reduction in biomass $(24.3 \%)$ compared to the other stations dominated by $G$. acerosa (59\%). This could explain the absence of reductions in the density of most meiofaunal groups in the trampled area of this station. On the other hand, it does not explain the significant negative effect on Polychaeta, nor the large increase in densities of Ostracoda and Tardigrada. Although somewhat speculative, there are two non-exclusive alternative hypotheses that may explain these results. It is likely that the effect of human trampling on $C$. papillosus reduces the density of a predator that spe- cializes in the groups Ostracoda and Tardigrada. Potentially, this group could be Polychaeta, whose densities were significantly reduced and whose family Syllidae, which consists of predators, is a frequent representative of this phytal habitat, comprising over $60 \%$ of polychaete individuals (Santos, PJP data not published). Another possible explanation involves the possible presence of very specialized genera within Tardigrada (Echiniscus) and Ostracoda (members of Xestoleberidae and Paradoxostomatidae) that, together with a few other meiofauna species, can feed directly on their phytal substratum by piercing the cells and sucking out the cytoplasm (Giere, 2009). Trampling may damage Chondrophycus, and though it does not significantly reduce its biomass, this physical disturbance may expose the algae and extrude part of its cytoplasm, which may function as a chemical signal to attract the specialized herbivores.

In this study, the different responses of the meiofaunal groups in each alga species clearly increased the variability of the assemblage structure under trampling conditions. Applying an observational experimental approach, Casu et al. (2006a) found high spatial variability, and out of the entire 15 taxa examined only Amphipoda (caprellids) and Isopoda showed significantly different abundances between visited and control locations. The authors suggest that the tourist load, which is concentrated exclusively in July and August, did not have a negative effect on the zoobenthic assemblage, with the level of trampling intensity and/or duration being insufficient to cause significant effects. They also suggest that for the taxa Amphipoda and Isopoda the differences were probably not due to tourist visits, which suggests that natural factors, such as substrate type, algal assemblage composition and biotic interactions among organisms, could play a key role. Although it is possible that the number of tourists did not have a negative impact on this assemblage, the results presented here suggest that environmental variations inherent to the different locations of the stations in the study area of Casu et al. (2006a), such as those mentioned by the authors, prevented the real effect due to trampling in the visited area from being perceived.

Van de Werfhorst and Pearse (2007) studied the rocky intertidal platform in Santa Cruz, California, where two earlier studies failed to find significant differences in the biota among sites despite the documented differences in human visitation, and emphasized the importance of an appropriate sampling design. It was necessary to increase the statistical power of the analyses by minimizing sample variation among sites in order to detect the differences that may be caused by disturbances such as human trampling. To detect significant differences in mussel populations (Mytilus californianus) at several sites on the California coast due to impacts from human visitors, Smith et al. (2008) applied, as was done here, a paired design to minimize site-to-site differences due to natural factors. 
The present study reconciles the results of the predominantly very significant negative effects caused by human trampling found by manipulative experimental studies, with the difficulties involved in observational studies for finding significant trampling effects on the density of benthic animals. It is very likely that problems related to sampling design, in addition to problems related to the different response patterns of the groups according to the composition of the phytal habitat, may have impeded or prevented previous studies from distinguishing the effect of trampling from that of natural variations.

The use of the information at the level of major taxonomic groups, together with an appropriate sampling design, has proved to be a fast and efficient tool for assessing the impact of trampling. Moreover, the results presented here demonstrate for the first time the relationship between the divergent response patterns of meiofaunal invertebrates to human trampling depending on the species composition of the phytal substrate.

Three main factors should be considered to assess the impact of human trampling on meiofauna: that different algal species are affected differently by human trampling (Milazzo et al., 2002, 2004); that meiofaunal assemblages on different algal substrates may differ considerably (Hicks, 1977; Frame et al., 2007); and finally, that the meiofauna assemblage may respond differently to the same source of disturbance depending on the differing characteristics of the algal habitats that they inhabit (this study).

The negative impacts of trampling on major meiofauna taxa should draw attention to the possible effects of this human disturbance on other taxonomic or ecological groups, and also to its consequences for the ecological and economic "services" that coral reefs provide.

\section{ACKNOWLEDGEMENTS}

V.C. Sarmento acknowledges a MSc scholarship, P.J.P. Santos acknowledges a research fellowship (305609/2004-1), and A.F.S. Barreto an undergraduate scholarship, all from CNPq. Thanks are due to Dr. Janet W. Reid for the English language revision, to Dr. Carlos D. Perez for the Spanish language revision and to Dr. Adilma M. Cocentino for the algae identifications. Thanks are also due to two anonymous reviewers for providing comments that improved the manuscript.

\section{REFERENCES}

Alcantara, R., B.P. Ferreira and P. Travassos. - 2004. A pesca artesanal e o turismo em Porto de Galinhas, Pernambuco. Bol. Téc. Cient. CEPENE, 12(1): 195-207.

Andersen, U.V. - 1995. Resistance of Danish coastal vegetation types to human trampling. Biol. Conserv., 71: 223-230.

Araújo, R., S. Vaselli, M. Almeida, E. Serrão and I. Sousa-Pinto. 2009. Effects of disturbance on marginal populations: human trampling on Ascophyllum nodosum assemblages at its southern distribution limit. Mar. Ecol. Prog. Ser., 378: 81-92.

Arroyo, N.L., M. Maldonado, R. Pérez-Portela and J. Benito. -
2004. Distribution patterns of meiofauna associated with a sublittoral Laminaria bed in the Cantabrian Sea (north-eastern Atlantic). Mar. Biol., 144: 231-242.

Bally, R. and C.L. Griffiths. - 1989. Effects of human trampling on an exposed rocky shore. Int. J. Environ. Stud., 34: 115-125.

Batista, J.B., R.M.V. Leonel and M.A.J. Costa. - 2009. Population characteristics of Microphrys bicornutus (Brachyura, Mithracidae) on the phytal Halimeda opuntia (Chlorophyta, Halimedaceae), on reef area submitted to human visitation, in João Pessoa, Paraíba, Brazil. Iheringia, Sér. Zool., 99(1): 44-52.

Brosnan, D.M. and L.L. Crumrine. - 1994. Effects of human trampling on marine rocky shore communities. J. Exp. Mar. Biol. Ecol., 177(1): 79-97.

Brown, P.J. and R.B. Taylor. - 1999. Effects of trampling by humans on animals inhabiting coralline algal turf in the rocky intertidal. J. Exp. Mar. Biol. Ecol., 235: 45-53.

Casu, D., G. Ceccherelli, M. Curini-Galletti and A. Castelli. 2006a. Human exclusion from rocky shores in a Mediterranean marine protected area (MPA): An opportunity to investigate the effects of trampling. Mar. Environ. Res., 62: 15-32.

Casu, D., G. Ceccherelli and A. Castelli. - 2006b. Immediate effects of experimental human trampling on mid-upper intertidal benthic invertebrates at the Asinara Island MPA (NW Mediterranean). Hydrobiologia, 555: 271-279.

Casu, D., G. Ceccherelli, M. Curini-Galletti and A. Castelli. - 2006c. Short-term effects of experimental trampling on polychaetes of a rocky intertidal substratum (Asinara Island MPA, NW Mediterranean). Sci. Mar., 70(3): 179-186.

Clarke, K.R. and R.M. Warwick. - 1994. Changes in marine communities: an approach to statistical analysis and interpretation. Bourne Press, Bournemouth, 128 pp.

Costa Jr., O.S., M. Nimmo and M.J. Attrill. - 2008. Coastal nutrification in Brazil: A review of the role of nutrient excess on coral reef demise. J. South Am. Earth Sci., 25: 257-270.

Coull, B.C. - 1988. Ecology of the marine meiofauna. In: R.P. Higgins and H. Thiel (eds.), Introduction to the Study of Meiofauna, pp. 18-38. Smithsonian Inst. Press, Washington.

Danovaro, R., M. Scopa, C. Gambi and S. Franschetti. - 2007. Trophic importance of subtidal metazoan meiofauna: evidence from in situ exclusion experiments on soft and rocky substrates. Mar. Biol., 152: 339-350.

Davenport, J. and J.L. Davenport. - 2006. The impact of tourism and personal leisure transport on coastal environments: A review. Estuar. Coast. Shelf Sci., 67: 280-292.

Defeo, O., A. McLachlan, D.S. Schoeman, T.A. Schlacher, J. Dugan, A. Jones, M. Lastra and F. Scapini. - 2009. Threats to sandy beach ecosystems: A review. Estuar. Coast. Shelf Sci., 81: 1-12.

Dye, H.A. - 2006. Persistent effects of physical disturbance on meiobenthos in mangrove sediments. Mar. Environ. Res., 62: 341-355.

Fanini, L., C.M. Cantarino and F. Scapini. - 2005. Relationships between the dynamics of two Talitrus saltator populations and the impacts of activities linked to tourism. Oceanologia, 47(1): 93-112.

Ferreira, M.N. and S. Rosso. - 2009. Effects of human trampling on a rocky shore fauna on the São Paulo coast, southeastern Brazil. Braz. J. Biol., 69(4): 993-999.

Fletcher, H. and C.L.J. Frid. - 1996. Impact and management of visitor pressure on rocky intertidal algal communities. Aquat. Conserv.: Mar. Freshw. Ecosyst., 6(4): 287-297.

Frame, K., G. Hunt and K. Roy. - 2007. Intertidal meiofaunal biodiversity with respect to different algal habitats: a test using phytal ostracodes from Southern California. Hydrobiologia, 586: $331-342$

Gheskiere, T., M. Vincx, J.M. Weslawski, F. Scapini and S. Degraer. - 2005. Meiofauna as descriptor of tourism-induced changes at sandy beaches. Mar. Environ. Res., 60: 245-265.

Giere, O. - 2009. Meiobenthology: The microscopic motile fauna of aquatic sediments. $2^{\text {nd }}$ ed. Springer-Verlag, Berlin.

Gibbons, M.J. and C.L. Griffiths. - 1986. A comparison of macrofaunal and meiofaunal distribution and standing stock across a rocky shore, with an estimate of their productivities. Mar. Biol., 93: 181-188.

Grunewald, R. - 2006. Assessment of damages from recreational activities on coastal dunes of the Southern Baltic Sea. J. Coast. Res., 22(5): 1145-1157.

Hicks, G.R.F. - 1977. Species associations and seasonal population 
densities of marine phytal harpacticoid copepods from Cook Strait. N.Z. J. Mar. Freshwat. Res., 11: 621-643.

Hsu, C.B., C.P. Chen and H.L. Hsieh. - 2009. Effects of sediment compaction on macroinfauna in a protected coastal wetland in Taiwan. Mar. Ecol. Prog. Ser., 375: 73-83.

Jenkins, C., M.E. Haas, A. Olson and J.L. Ruesink. - 2002. Impacts of trampling on a rocky shoreline of San Juan Island, Washington, USA. Nat. Areas J., 22(4): 260-269.

Johnson, G.E.L., M.J. Attrill, E.V. Sheehan and P.J. Somerfield. 2007. Recovery of meiofauna communities following mudflat disturbance by trampling associated with crab-tiling. Mar. Environ. Res., 64: 409-416.

Keough, M.J. and G.P. Quinn. - 1998. Effects of periodic disturbances from trampling on rocky intertidal algal beds. Ecol. Appl,. 8(1): 141-161.

Kerbiriou, C., I. Leviol, F. Jiguet and R. Julliard. - 2008. The impact of human frequentation on coastal vegetation in a biosphere reserve. J. Environ. Manage., 88: 715-728.

Leão, Z.M.A.N. and J.M.L. Dominguez. - 2000. Tropical coast of Brazil. Mar. Pollut. Bull., 41(1-6): 112-122.

Liddle, M.J. - 1997. Recreational ecology: the ecological impact of outdoor recreation and ecotourism. Chapman and Hall, London.

Maida, M. and B.P. Ferreira. - 1997. Coral reefs of Brazil: an overview. In: H.A. Lessios and I.G. Macintyre (eds.), Proceedings of the $8^{\text {th }}$ International Coral Reef Symposium, Vol. 1, pp. 263274. Smithsonian Tropical Research Institute, Panama.

Milazzo, M., R. Chemello, F. Badalamenti and S. Riggio. - 2002. Short-term effect of human trampling on the upper infralittoral macroalgae of Ustica Island MPA (western Mediterranean, Italy). J. Mar. Biol. Ass. U.K., 82: 745-748.

Milazzo, M., F. Badalamenti, S. Riggio and R. Chemello. - 2004. Patterns of algal recovery and small-scale effects of canopy re- moval as a result of human trampling on a Mediterranean rocky shallow assemblage. Biol. Conserv., 117: 191-202.

Pinn, E.H. and M. Rodgers. - 2005. The influence of visitors on intertidal biodiversity. J. Mar. Biol. Ass. U.K., 85: 263-268.

Povey, A. and M.J. Keough. - 1991. Effects of trampling on plant and animal populations on rocky shores. Oikos, 61: 355-368.

Schiel, D.R. and D.I. Taylor. - 1999. Effects of trampling on a rocky intertidal algal assemblage in southern New Zealand. J. Exp. Mar. Biol. Ecol., 235: 213-235.

Smith, J.R., P. Fong and R.F. Ambrose. - 2008. The impacts of human visitation on mussel bed communities along the California coast: are regulatory marine reserves effective in protecting these communities? Environ. Manage., 41: 599-612.

Van De Werfhorst, L.C. and J.S. Pearse. - 2007. Trampling in the rocky intertidal of central California: a follow-up study. Bull. Mar. Sci., 81(2): 245-254.

Veloso, V.G., E.S. Silva, C.H.S. Caetano and R.S. Cardoso. -2006 Comparison between the macroinfauna of urbanized and protected beaches in Rio de Janeiro State, Brazil. Biol. Conserv., 127: 510-515.

White, A.T., H.P. Vogt and T. Arin. - 2000. Philippine coral reefs under threat: the economic losses caused by reef destruction. Mar. Poll. Bull., 40(7): 598-605.

Wynberg, R.P. and G.M. Branch. - 1997. Trampling associated with bait-collection for sandprawns Callianassa kraussi Stebbing: effects on the biota of an intertidal sandflat. Environ. Conserv., 24(2): 139-148.

Zar, J.H. - 1996. Biostatistical Analysis. $3^{\text {rd }}$ ed., Prentice-Hall, New Jersey.

Scient. ed.: X. Turon.

Received October 15, 2010. Accepetd February 4, 2011.

Published online June 3, 2011. 